\title{
Zróżnicowanie temperatury powietrza w skali lokalnej w różnych typach krajobrazu Polski*
}

\author{
Local-scale air-temperature differences \\ in various types of Poland's landscape
}

\author{
ANNA KUNERT \\ Instytut Geografii i Przestrzennego Zagospodarowania im. S.Leszczyckiego PAN, \\ 00-818 Warszawa, ul. Twarda 51/55; a.kunert@twarda.pan.pl,

\section{KRZYSZTOF BŁAŻEJCZYK} \\ Wydział Geografii i Studiów Regionalnych, Uniwersytet Warszawski, \\ 00-927 Warszawa, Krakowskie Przedmieście 30; kblazejczyk@uw.edu.pl
}

Zarys treści. Zróżnicowanie klimatu w skali lokalnej jest przedmiotem licznych badań. Szczególnie wrażliwa na warunki lokalne jest temperatura powietrza. Jej wartości obserwowane w różnych typach krajobrazu wyraźnie różnią się od tzw. warunków standardowych. Celem pracy jest próba ilościowego określenia wpływu różnych elementów krajobrazu na lokalne warunki termiczne. W opracowaniu wykorzystano wyniki badań terenowych dotyczących termicznych cech klimatu w skali lokalnej, prowadzonych w latach 2001-2008 w 33 miejscach na obszarze Polski. Znaleziono wyraźne zależności pomiędzy niektórymi cechami krajobrazu (np. rodzaj i zwartość zabudowy, wielkość doliny, ekspozycja zboczy) a wartościami temperatury powietrza obserwowanymi w skali lokalnej.

Słowa kluczowe: Polska, klimat lokalny, temperatura powietrza, rzeźba terenu, zagospodarowanie terenu.

\section{Wstęp}

Jednym z podstawowych celów badań topoklimatycznych jest określenie zróżnicowania przestrzennego różnych elementów klimatu w skali lokalnej. Zrealizowanie tego celu nie jest możliwe na podstawie danych ze standardowych stacji meteorologicznych. Rejestrują one bowiem wartości elementów meteorologicznych na otwartym płaskim terenie, z horyzontem o niewielkim stopniu zasłonięcia, na wysokości $2,0 \mathrm{~m}$ nad powierzchnią pokrytą trawą o wysokości

\footnotetext{
* Praca częściowo dofinansowana przez Ministra Nauki i Szkolnictwa Wyższego, w ramach specjalnego projektu badawczego COST/37/2006.
} 
$10 \mathrm{~cm}$. Dzięki temu można prześledzić wahania elementów meteorologicznych pod wpływem ogólnej cyrkulacji atmosfery.

W badaniach topoklimatycznych przyczyn różnic przestrzennych klimatu poszukuje się natomiast $\mathrm{w}$ warunkach lokalnych: cechach rzeźby terenu, w zagospodarowaniu terenu (m.in. w miejscach o różnym stopniu zasłonięcia horyzontu) czy też w cechach fizycznych podłoża atmosfery (m.in. szorstkość, przewodność i pojemność cieplna). Interesują nas nie tyle wartości poszczególnych elementów meteorologicznych (bo te są przede wszystkim zależne od ogólnych cech fizycznych zalegającej masy powietrza), ile ich odchylenia w stosunku do tzw. warunków standardowych. Zakłada się przy tym, że kierunek tych odchyleń jest stałą, topoklimatyczną cechą danego fragmentu terenu. Sama wielkość odchyleń może się natomiast różnić w odmiennych warunkach pogodowych (Geiger, 1969; Lee, 1978; Oke, 1987; Paszyński i inni, 1999). Praktycznym problemem przy organizacji badań topoklimatycznych jest zatem uzyskanie informacji z obszaru odpowiadającego warunkom standardowym. Bardzo często zakłada się specjalny punkt pomiarowy, który ma reprezentować takie właśnie warunki. Na etapie interpretacji danych obserwacyjnych rodzą się jednak pytania, czy i na ile wyniki uzyskane ze stanowisk pomiarowych określanych jako „teren otwarty” odpowiadają standardowym warunkom meteorologicznym, a więc podlegającym czynnikom nie lokalnym, a cyrkulacyjnym.

Celem pracy jest próba ilościowego określenia wpływu różnych elementów krajobrazu w skali lokalnej na panujące w ich obrębie warunki termiczne w ciepłej porze roku. Wykorzystano w tym celu wyniki badań topoklimatycznych prowadzonych w różnych typach krajobrazu lokalnego, w różnych regionach Polski w latach 2001-2008.

\section{Materiały i metoda}

Badania prowadzone były w latach 2001-2008 w 33 miejscowościach w Polsce, reprezentujących różne regiony oraz typy makro- i topoklimatu (ryc. 1). Temperatura powietrza mierzona była na wysokości 1,2-1,5 m nad poziomem gruntu przy użyciu rejestratorów HOBO Pro (Onset Computer Corp.), zabezpieczonych plastikowymi osłonami antyradiacyjnymi.

Serie badań trwały od 2 tygodni do 6 miesięcy i obejmowały ciepłą część roku (kwiecień-październik). Temperatura powietrza była mierzona co 10 sekund i rejestrowana jako 10-minutowa średnia. Zapisane wartości były podstawą do obliczeń charakterystyk temperatury. Średnią dobową temperaturę powietrza $\left(T_{\text {avg }}\right)$ obliczono jako średnią ze 144 10-minutowych wartości rejestrowanych każdej doby. Jako maksymalną $\left(T_{\max }\right)$ i minimalną $\left(T_{\min }\right)$ dobową temperaturę przyjęto najwyższą i najniższą temperaturę z wartości zarejestrowanych każdego dnia. 
W celu określenia odchyleń temperatury powietrza od tzw. warunków standardowych jej wartości dobowe (średnie, maksymalne i minimalne) były dla każdej serii pomiarowej odniesione do analogicznych danych z tego samego okresu z najbliższej stacji meteorologicznej (reprezentującej tzw. warunki standardowe). Pozwoliło to na wyeliminowanie wpływu ogólnych cech atmosfery na warunki termiczne i skoncentrowanie się na roli czynników lokalnych w kształtowaniu temperatury powietrza. Umożliwiło to także zbadanie, czy stanowiska określane w dokumentacjach każdej serii pomiarowej jako „teren otwarty” odpowiadały standardowym warunkom meteorologicznym. Obliczono odchylenia temperatury ( $\left.\mathrm{d} T_{\text {avg }}, \mathrm{d} T_{\max }, \mathrm{d} T_{\min }\right)$ na terenach o różnym zagospodarowaniu i o różnych typach mikrorzeźby od dobowych wartości temperatury $\left(T_{\text {avg }}, T_{\max }\right.$, $\left.T_{\min }\right)$ w punkcie odniesienia.

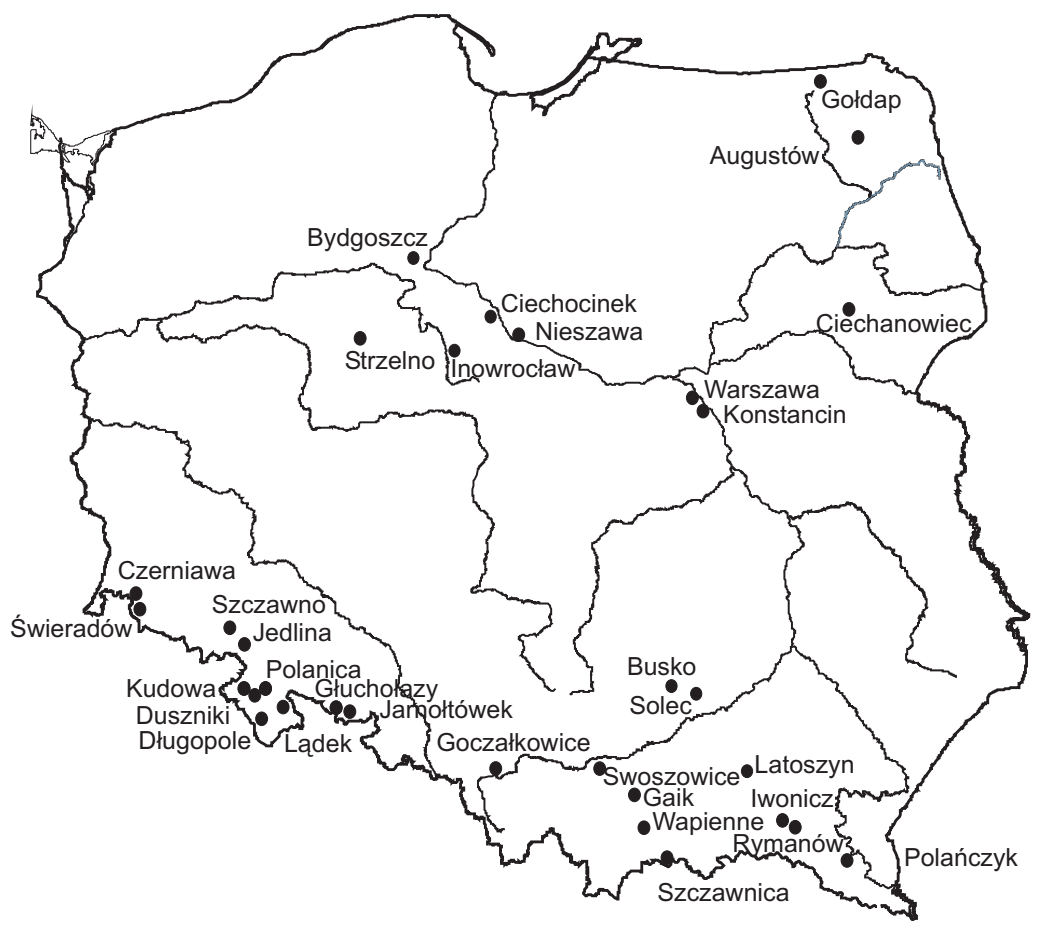

Ryc. 1. Miejscowości objęte badaniami w latach 2001-2008

Sites studied in the years 2001-2008

Dane z obserwacji zostały podzielone na dwie grupy zdefiniowane przez ogólny typ krajobrazu: obszary równinne (niziny i wyżyny) oraz obszary górskie.

W każdej z tych grup dominują inne czynniki modyfikujące warunki klimatu lokalnego. Na obszarach równinnych zróżnicowanie termiczne jest kształ- 
towane w głównej mierze przez rodzaj zagospodarowania i pokrycia terenu (Fortuniak, 2003, Błażejczyk, 1996, 2002; Błażejczyk i inni, 2006; Błażejczyk i Kunert, 2006; Oke, 1987; Paszyński i inni, 1999). Na obszarach górskich natomiast, różnice termiczne były analizowane z dwóch punktów widzenia: rodzaju zagospodarowania oraz rzeźby terenu (Hess, 1968; Trepińska, 2002).

\section{Wyniki}

Uwzględniając przyjęte wyżej założenia analiza wyników została przeprowadzona oddzielnie dla obszarów równinnych i obszarów górskich.

\section{Obszary równinne}

Badaniami objęto obszary zagospodarowane w różny sposób:

1) zabudowane:

- zabudowa luźna (obszar zabudowany o małej gęstości zabudowy, budynki rozproszone, usytuowane na dużych działkach, wśród ogrodów i zadrzewień);

- zabudowa zwarta (obszar zabudowany o dużej gęstości zabudowy, niewielkie odległości pomiędzy budynkami powodujące silne zacienienie w różnych porach dnia);

dodatkowym kryterium dla obszarów zabudowanych była wysokość zabudowy: niska (do 3 kondygnacji) oraz wysoka (powyżej 3 kondygnacji).

2) lasy oraz zabudowa śródleśna,

3) parki miejskie,

4) teren otwarty (niezbyt rozległy płaski obszar niezabudowany i niezalesiony, ze stosunkowo swobodnym przepływem powietrza) (tab. 1).

Analizując odchylenia średniej temperatury dobowej można zauważyć, że ich największe średnie wartości występują na terenach zabudowy - zarówno luźnej, jak i zwartej. Wynoszą one przeciętnie od 0,5 do $1,0^{\circ} \mathrm{C}$. Na obszarze parków, lasów i na tzw. „terenach otwartych” wartości $\mathrm{d} T_{\text {avg }}$ są natomiast bliskie zeru, co oznacza mało znaczącą różnicę w stosunku do stacji meteorologicznej (ryc. 2).

W codziennej aktywności człowieka szczególnie ważne są warunki termiczne podczas godzin dziennych. Są one reprezentowane przez maksymalną temperaturę dobową $\left(T_{\max }\right)$. Jej największe średnie wartości notuje się na terenach zabudowanych, natomiast największy zakres odchyleń obserwuje się w zabudowie niskiej luźnej $\left(\mathrm{d} T_{\max }\right.$ od $-0,5$ do $4,5^{\circ} \mathrm{C}$ ) i zwartej ( $\mathrm{d} T_{\max }$ od $-1,5$ do $6,5^{\circ} \mathrm{C}$ ). Wartości $\mathrm{d} T_{\max }$ na obszarach o zabudowie wysokiej są dużo niższe i mieszczą się $\mathrm{w}$ granicach $0-2^{\circ} \mathrm{C}$. Znaczne wahania $\mathrm{d} T_{\max }$ wynikają z usytuowania punktów pomiarowych. Na terenach zabudowanych były one niekiedy zlokalizowane w miejscach silnie nasłonecznionych przez środkową część dnia. Duża emi- 
Tabela 1. Charakterystyki badanych obszarów równinnych

Characteristics of the studied plan areas

\begin{tabular}{|c|c|c|c|c|c|}
\hline $\begin{array}{c}\text { Miejscowość } \\
\text { Locality }\end{array}$ & $\begin{array}{l}\text { Liczba } \\
\text { mieszkań- } \\
\text { ców } \\
\text { (tys.) } \\
\text { No. of inha- } \\
\text { bitants } \\
\text { ('000) }\end{array}$ & $\begin{array}{c}\text { Rodzaj } \\
\text { zagospodaro- } \\
\text { wania terenu } \\
\text { Type of land } \\
\text { use }\end{array}$ & \begin{tabular}{|c|} 
Najbliż- \\
sza stacja \\
meteo- \\
rologiczna \\
Nearest \\
meteorologi- \\
cal stadion
\end{tabular} & $\begin{array}{l}\text { Czas trwania } \\
\text { pomiarów } \\
\text { Period of } \\
\text { measure- } \\
\text { ment }\end{array}$ & $\begin{array}{l}\text { Region fizycz- } \\
\text { nogeograficzny } \\
\text { (wg Kondrac- } \\
\text { kiego, 2000) } \\
\text { Physico-geogra- } \\
\text { phical region } \\
\text { (after Kondracki, } \\
\text { 2000) }\end{array}$ \\
\hline Augustów & 30 & zln, zs, las & Suwałki & $\begin{array}{l}2 \text { miesiące } \\
2 \text { months }\end{array}$ & $\begin{array}{l}\text { Pojezierze } \\
\text { Litewskie }\end{array}$ \\
\hline Busko & 17 & $\begin{array}{l}\text { zln, zlw, zzn, } \\
\text { park, to }\end{array}$ & Sandomierz & $\begin{array}{l}2 \text { miesiące } \\
2 \text { months }\end{array}$ & $\begin{array}{l}\text { Niecka } \\
\text { Nidziańska }\end{array}$ \\
\hline Bydgoszcz & 360 & zln, zlw, zzw & Bydgoszcz & $\begin{array}{l}2 \text { miesiące } \\
2 \text { months }\end{array}$ & $\begin{array}{l}\text { Kotlina } \\
\text { Toruńska }\end{array}$ \\
\hline Ciechanowiec & 5 & $\begin{array}{l}\text { zln, zzn, zzw, } \\
\text { to }\end{array}$ & $\begin{array}{l}\text { Ciechano- } \\
\text { wiec }\end{array}$ & $\begin{array}{l}2 \text { miesiące } \\
2 \text { months }\end{array}$ & $\begin{array}{l}\text { Nizina } \\
\text { Podlaska }\end{array}$ \\
\hline Ciechocinek & 11 & $\begin{array}{l}\text { zln, zzn, zs, } \\
\text { park }\end{array}$ & Toruń & $\begin{array}{l}2 \text { miesiące } \\
2 \text { months }\end{array}$ & $\begin{array}{l}\text { Kotlina } \\
\text { Toruńska }\end{array}$ \\
\hline Goczałkowice & 6 & zzn; las & Bielsko-Biała & $\begin{array}{l}1,5 \text { miesiąca } \\
1.5 \text { month }\end{array}$ & $\begin{array}{l}\text { Kotlina } \\
\text { Oświęcimska }\end{array}$ \\
\hline Gołdap & 13,5 & zzw, las & Kętrzyn & $\begin{array}{l}1 \text { miesiąc } \\
\text { month }\end{array}$ & $\begin{array}{l}\text { Pojezierze } \\
\text { Litewskie }\end{array}$ \\
\hline Inowrocław & 76 & $\mathrm{zln}, \mathrm{zzn}, \mathrm{zzW}$ & Inowrocław & $\begin{array}{l}2 \text { miesiące } \\
2 \text { months }\end{array}$ & $\begin{array}{l}\text { Pojezierze } \\
\text { Wielkopolskie }\end{array}$ \\
\hline Konstancin & 16 & $\begin{array}{l}\text { zln, zzn, zs, } \\
\text { las }\end{array}$ & $\begin{array}{l}\text { Warszawa- } \\
\text { Okęcie }\end{array}$ & $\begin{array}{l}\text { 3,5 miesiąca } \\
3.5 \text { months }\end{array}$ & $\begin{array}{l}\text { Nizina Środkowo- } \\
\text { mazowiecka }\end{array}$ \\
\hline Nieszawa & 2 & zln, zwn & Toruń & $\begin{array}{l}2,5 \text { miesiąca } \\
2 \text { months }\end{array}$ & $\begin{array}{l}\text { Kotlina } \\
\text { Toruńska }\end{array}$ \\
\hline Solec & 0,9 & zzw, park, to & Sandomierz & $\begin{array}{l}2 \text { miesiące } \\
2 \text { months }\end{array}$ & $\begin{array}{l}\text { Niecka } \\
\text { Nidziańska }\end{array}$ \\
\hline Strzelno & 6 & zln, zzn & Poznań & $\begin{array}{l}2 \text { miesiące } \\
2 \text { months }\end{array}$ & $\begin{array}{l}\text { Pojezierze } \\
\text { Wielkopolskie }\end{array}$ \\
\hline Swoszowice & 20 & $\begin{array}{l}\text { zln, zs, to, } \\
\text { park }\end{array}$ & $\begin{array}{l}\text { Kraków- } \\
\text { Balice }\end{array}$ & $\begin{array}{l}5 \text { tygodni } \\
5 \text { weeks }\end{array}$ & $\begin{array}{l}\text { Pogórze Zachod- } \\
\text { niobeskidzkie }\end{array}$ \\
\hline Warszawa & 1707 & $\begin{array}{l}\text { zln, zzn, zzw, } \\
\text { las, park; to }\end{array}$ & $\begin{array}{l}\text { Warszawa- } \\
\text { Okęcie }\end{array}$ & $\begin{array}{l}6 \text { miesięcy } \\
6 \text { months }\end{array}$ & $\begin{array}{l}\text { Nizina Środkowo- } \\
\text { mazowiecka }\end{array}$ \\
\hline
\end{tabular}

Skróty / Abbreviations: zln - zabudowa luźna niska / low, non-dense settlement; zlw - zabudowa luźna wysoka / high, non-dense settlement, zzn - zabudowa zwarta niska / low, non-dense settlement; zzw - zabudowa zwarta wysoka / high, dense settlement, zs - zabudowa śródleśna / middle-forest settlement; to - teren otwarty / open area; park - park; las - forest. 


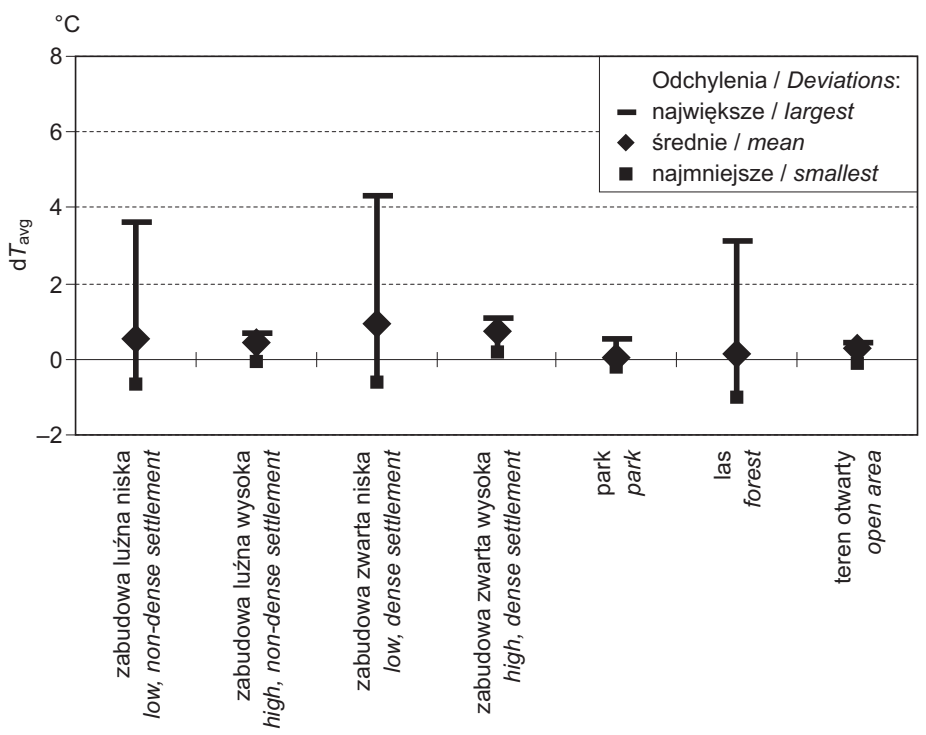

Ryc. 2. Odchylenia (w odniesieniu do warunków standardowych) średniej dobowej temperatury powietrza $\left(\mathrm{d} T_{\mathrm{avg}}\right) \mathrm{w}$ różnych typach zagospodarowania terenu na obszarach równinnych

Deviations (from standard conditions) characterising mean daily air temperature $\left(\mathrm{d} T_{\mathrm{avg}}\right)$ in land on plains put to various kinds of land use

sja ciepła z nagrzanego podłoża i z obiektów otaczających czujnik termometru powodowała podwyższenie temperatury powietrza. Część punktów znajdowała się natomiast w miejscach, które w okresie zbliżonym do dobowego maksimum temperatury były zacienione. Efektem tego była niższa niż w warunkach standardowych temperatura maksymalna. Uzyskane wyniki dobrze ilustrują dużą zmienność przestrzenną temperatury powietrza obserwowanej w godzinach dziennych wśród zabudowy.

$\mathrm{Na}$ terenach określanych w dokumentacji badań jako „otwarte” temperatura maksymalna jest kształtowana podobnie jak na stacjach meteorologicznych, a $\mathrm{d} T_{\max }$ nie przekracza $1^{\circ} \mathrm{C}$ (ryc. 3 ).

Odchylenia minimalnej temperatury dobowej na terenach zurbanizowanych ukazują występowanie miejskiej wyspy ciepła. Najcieplejsze wczesnym rankiem są tereny zabudowy zwartej - niskiej i wysokiej oraz luźnej niskiej. Temperatura powietrza może tam być o $2-3^{\circ} \mathrm{C}$ wyższa niż w warunkach standardowych. Najniższa dobowa temperatura minimalna występuje na obszarach parków i terenów otwartych (ryc. 4). W przypadku lasów zakres odchyleń $\mathrm{d} T_{\min }$ jest duży. Średnie i najwyższe wartości temperatury minimalnej mogą być wyższe niż w warunkach standardowych, odpowiednio o $1 \mathrm{i} 3^{\circ} \mathrm{C}$. Jest to spowodowane zmniejszeniem wypromieniowania ciepła z dna lasu i jego zatrzymywaniem w warstwie podkoronowej. 


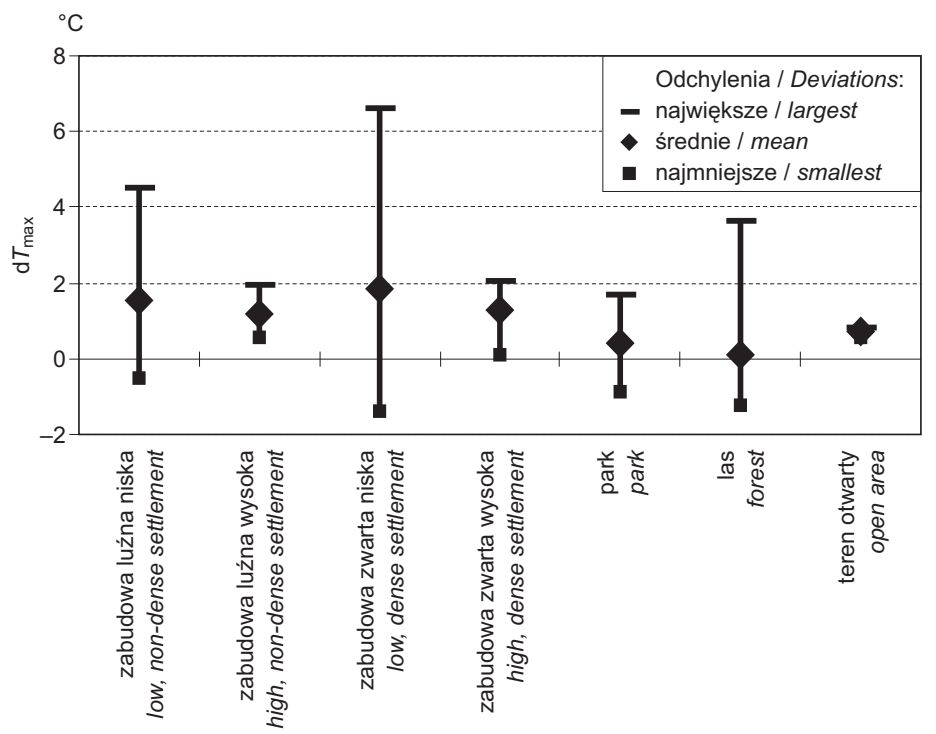

Ryc. 3. Odchylenia (w odniesieniu do warunków standardowych) maksymalnej dobowej temperatury powietrza $\left(\mathrm{d} T_{\max }\right)$ w różnych typach zagospodarowania terenu na obszarach równinnych

Deviations (from standard conditions) characterising maximum daily air temperature $\left(\mathrm{d} T_{\max }\right)$ in land on plains put to various kinds of land use

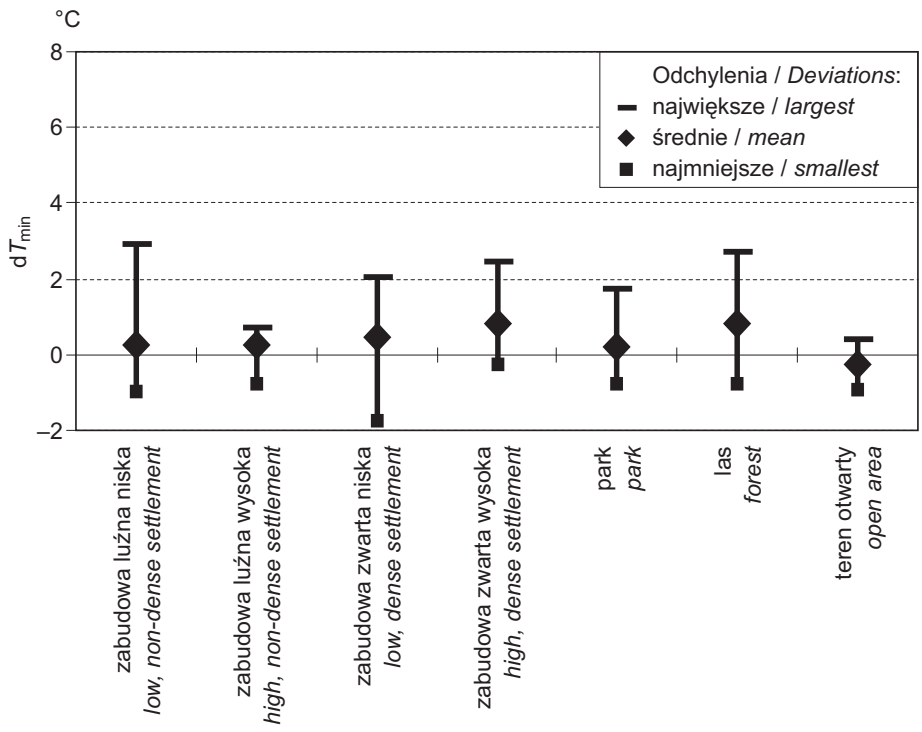

Ryc. 4. Odchylenia (w odniesieniu do warunków standardowych) minimalnej dobowej temperatury powietrza $\left(\mathrm{d} T_{\min }\right) \mathrm{w}$ analizowanych typach zagospodarowania terenu na obszarach równinnych

Deviations (from standard conditions) characterising minimum daily air temperature $\left(\mathrm{d} T_{\min }\right)$ in land on plains put to various kinds of land use 
Podsumowując można stwierdzić, że najcieplej podczas całej doby w porównaniu z warunkami standardowymi - było na obszarach zabudowanych. W lasach i na terenach otwartych zaobserwowano różne odchylenia temperatury podczas doby. W godzinach dziennych miały one temperaturę niższą, natomiast w nocy i rano obszary leśne są cieplejsze, a tereny otwarte - chłodniejsze niż obszar odniesienia. Na obszarach określanych jako „teren otwarty” wartości średnie temperatury minimalnej były zbliżone do warunków standardowych.

Na terenach parków średnia temperatura dobowa jest porównywalna z temperaturą $w$ warunkach standardowych, natomiast w ciągu dnia i nocą jest nieco wyższa, co wynika z silnego wpływu sąsiadującej zabudowy miejskiej na warunki termiczne.

Warunki termiczne obszarów zabudowanych wyraźnie zależą od ich struktury. Tereny o zabudowie luźnej, ze zwiększonym udziałem roślinności i swobodniejszym przepływem powietrza niż w przypadku zabudowy zwartej, mają łagodniejsze warunki termiczne.

Szczegółowej analizie poddano również warunki termiczne w lasach, próbując ocenić jaki wpływ na odchylenia temperatury mają rodzaj i gęstość zadrzewienia oraz występowanie na terenie leśnym zabudowy. Ogólnie można stwierdzić, że warunki termiczne są tam wyraźnie zróżnicowane i zależą od indywidualnych cech badanych powierzchni leśnych. W lasach iglastych gęstych odchylenie zarówno maksymalnej, jak i minimalnej dobowej temperatury ma wartości ujemne $\left(\mathrm{d} T_{\max }\right.$ od $-0,5^{\circ} \mathrm{C}$ do $-1,2^{\circ} \mathrm{C}$, $\mathrm{d} T_{\min }$ od $-0,2^{\circ} \mathrm{C}$ do $-0,7^{\circ} \mathrm{C}$ ). $\mathrm{W}$ lasach iglastych luźnych natomiast wartości temperatury skrajnej mają rozbieżne odchylenia $\mathrm{w}$ stosunku do punktu odniesienia i wynoszą ponad $1^{\circ} \mathrm{C}$ w przypadku d $T_{\max } \mathrm{i}-0,8^{\circ} \mathrm{C}-\mathrm{d} T_{\min }$ (ryc. 5). W lasach liściastych temperatura maksymalna w ciągu dnia jest o około $1^{\circ} \mathrm{C}$ niższa niż w warunkach standardowych, natomiast nocą i nad ranem są one wyraźne cieplejsze $\left(\mathrm{d} T_{\min }>1^{\circ} \mathrm{C}\right)$.

$\mathrm{Na}$ terenach leśnych bardzo silnie zaznacza się wpływ zabudowy śródleśnej na miejscowe warunki termiczne. W punkcie pomiarowym w Ciechocinku, położonym w luźnym lesie sosnowym otoczonym gęstą zabudową sanatoryjną temperatura maksymalna była o $3,6^{\circ} \mathrm{C}$ wyższa niż w punkcie odniesienia. Także $\mathrm{w}$ luźnym lesie iglastym, o stosunkowo swobodnym dopływie promieniowania słonecznego, $\mathrm{d} T_{\max }$ przyjmowało wartości dodatnie, równe $1,2^{\circ} \mathrm{C}$ (ryc. 5). Wnętrze lasu zatem nie zawsze w ciągu dnia jest chłodniejsze od warunków standardowych, a jego uprzywilejowanie termiczne może wynikać z obecności zabudowy lub okresowego, swobodnego dopływu promieni słonecznych do dna lasu.

Temperatura minimalna w punktach zlokalizowanych wśród zabudowy śródleśnej oraz w gęstych lasach liściastych była zawsze wyższa niż w warunkach standardowych, w zależności od struktury i gęstości zabudowy, o około $1-2,7^{\circ} \mathrm{C}$ (ryc. 5). Świadczy to zarówno o skutecznym zmniejszeniu nocnego wypromieniowania ciepła przez korony drzew, jak i o występowaniu miejskiej wyspy ciepła. 
W przypadku krajobrazów nizinnych wykonano również dodatkową analizę, mającą na celu stwierdzenie, czy na wartość odchyleń średniej, maksymalnej i minimalnej dobowej temperatury na terenach o różnym zagospodarowaniu ma wpływ wielkość miasta. Duża liczba mieszkańców i wynikająca z tego zwiększona emisja ciepła antropogenicznego sprzyja tworzeniu się miejskiej wyspy ciepła. Analiza tych zależności ukazuje zasięg i intensywność miejskiej wyspy ciepła na obszarach miast o różnej wielkości.

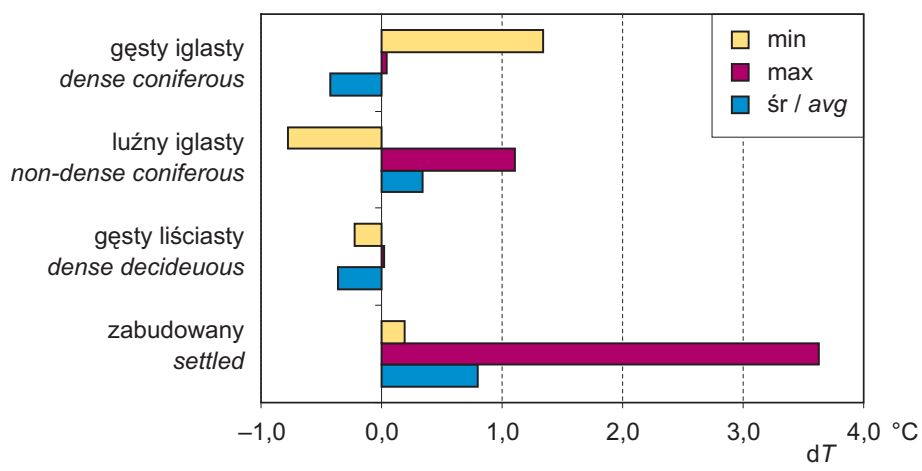

Ryc. 5. Odchylenia (dT): średnie (śr), najwyższe temperatury maksymalnej (max) i najniższe temperatury minimalnej (min) (w odniesieniu do warunków standardowych) na równinnych terenach leśnych

Deviations (dT): mean (avg), highest maximum temperatures (max) and lowest minimum temperatures (min) (in relation to standard conditions) in forested areas of plain land

Bardzo silna korelacja między wartościami odchyleń temperatury a wielkością miasta występuje w przypadku obszarów zabudowy zwartej i luźnej wysokiej. Na terenach o zabudowie wysokiej, odchylenia temperatury średniej ( $\left.\mathrm{d} T_{\mathrm{avg}}\right)$ są w 61\% (zabudowa zwarta) i 78\% (zabudowa luźna) zdeterminowane wielkością miasta i wzrastają wraz z nią (ryc. 6, 7).

Odchylenia temperatury minimalnej $\left(\mathrm{d} T_{\min }\right)$ są także ściśle powiązane z liczbą mieszkańców - współczynnik determinacji wynosi 75\% w przypadku zabudowy zwartej wysokiej i 90\% dla zabudowy luźnej wysokiej (ryc. 6, 7). Wartości temperatury minimalnej wzrastają wraz ze zwiększaniem się miasta i w przypadku terenów o zabudowie zwartej wysokiej mogą być w dużych miastach nawet o około $2^{\circ} \mathrm{C}$ wyższe niż w warunkach standardowych (ryc. 6).

Również tereny parków miejskich znajdują się pod wyraźnym wpływem miejskiej wyspy ciepła, pomimo że są to obszary pokryte szatą roślinną, która powinna niwelować ocieplający wpływ miasta. Zlokalizowane są bowiem najczęściej w centrach miast, a więc w skali ogólnomiejskiej na terenach najcieplejszych. 


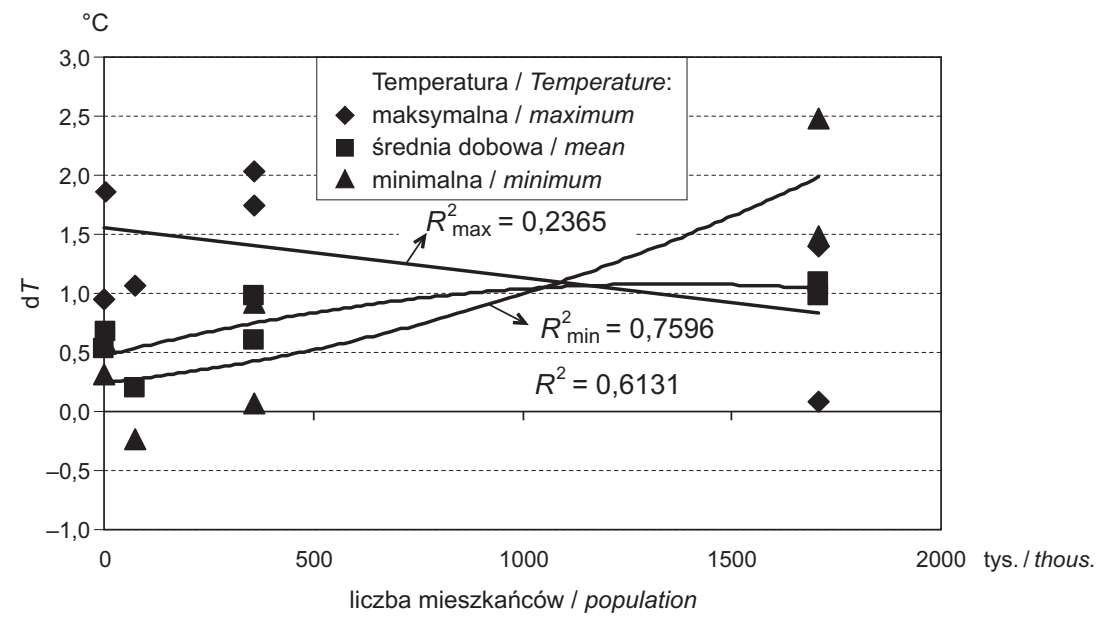

Ryc. 6. Średnie wartości odchyleń temperatury (dT) w zależności od wielkości miasta (wyrażonej liczbą mieszkańców) na obszarze zabudowy zwartej wysokiej

Mean deviations (dT) from 24-hour air temperatures, in relation to city size (expressed in population terms) in an area built up contiguously and with tall construction

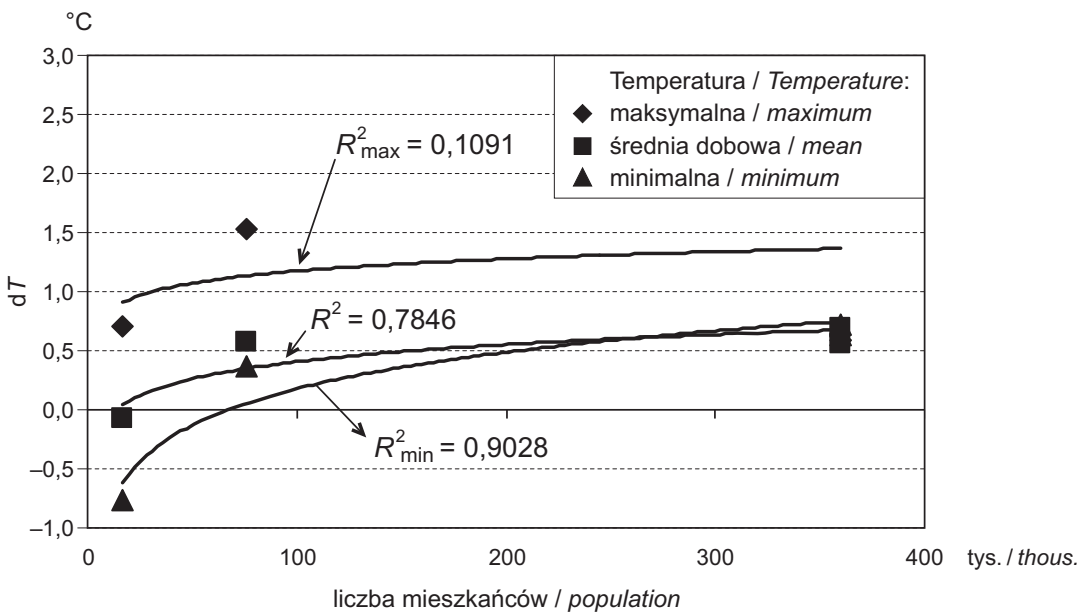

Ryc. 7. Średnie wartości odchyleń temperatury (dT) w zależności od wielkości miasta (wyrażonej liczbą mieszkańców) na obszarze zabudowy luźnej wysokiej

Mean deviations (dT) from 24-hour temperatures, in relation to city size (expressed in population terms) in an area with tall construction not densely built-up 
Obszary otaczające parki (są to z reguły duże ruchliwe ulice i zwarta zabudowa śródmiejska) znacznie je „ocieplają”. Odchylenia temperatury średniej na obszarze parków są w 54\% zależne od wielkości miasta, natomiast odchylenia temperatury minimalnej aż w 77\% (ryc. 8).

W przypadku terenów o zabudowie zwartej niskiej i luźnej niskiej nie zauważono istotnych korelacji z wielkością miasta - wynika to z pokrycia ich w znacznym stopniu szatą roślinną (ogrody przydomowe, zieleń miejska) modyfikującą warunki termiczne.

Znaleziono istotne statystycznie związki między wielkością miasta (wyrażoną liczbą mieszkańców $-x$ ) a wartościami odchyleń temperatury obserwowanej w obrębie zabudowy wysokiej: luźnej i zwartej, a także wewnątrz parków śródmiejskich. Opisują je następujące równania regresji:

- zabudowa zwarta wysoka: $\mathrm{d} T_{\mathrm{avg}}=-3,0 \cdot 10^{-7} \cdot x^{2}+0,0009 \cdot x+0,47$

- zabudowa luźna wysoka: $\quad \mathrm{d} T_{\mathrm{avg}}=0,2088 \cdot \operatorname{Ln}(x)-0,5543$

$\mathrm{d} T_{\min }=4,0 \cdot 10^{-7} \cdot x^{2}+0,0004 \cdot x+0,2449 ;$

$\mathrm{d} T_{\min }=0,4456 \cdot \operatorname{Ln}(x)-1,8737$;

- parki:

$\mathrm{d} T_{\max }=-0,2127 \cdot \operatorname{Ln}(x)+1,1254$

$\mathrm{d}_{\mathrm{avg}}=0,0783 \cdot \operatorname{Ln}(x)-0,1994$

$\mathrm{d} T_{\min }=0,3201 \cdot \operatorname{Ln}(x)-0,8732$.

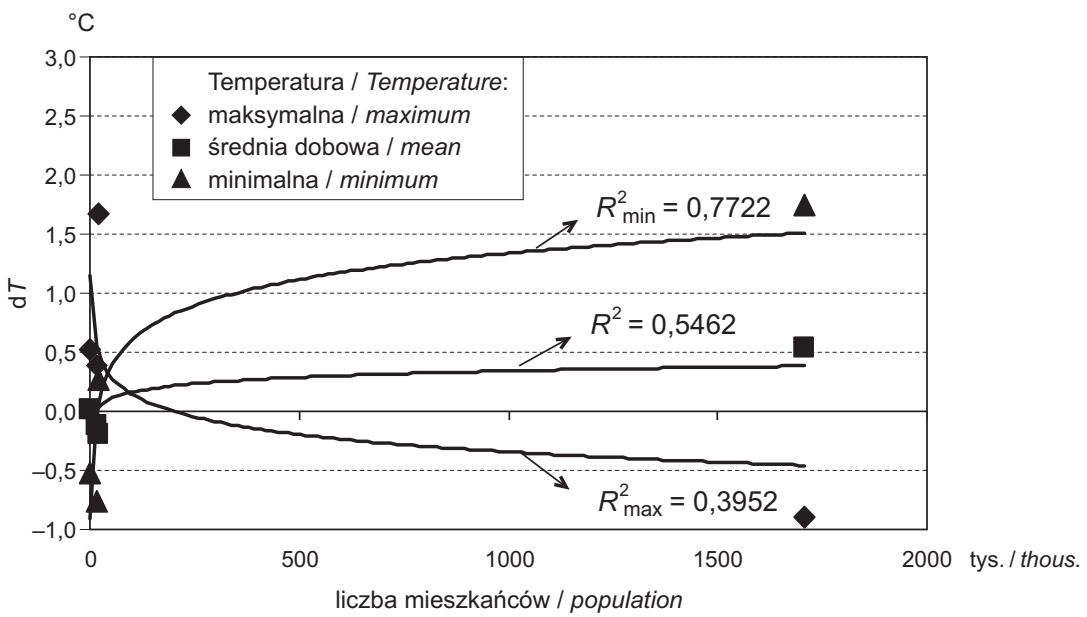

Ryc. 8. Średnie wartości odchyleń temperatury (dT): w zależności od wielkości miasta (wyrażoną liczbą mieszkańców) na obszarze parków

Mean deviations (dT) from 24-hour temperatures in relation to city size (expressed in population terms) in park areas 


\section{Obszary górskie}

W górach badania prowadzone były w 18 miejscowościach reprezentujących Sudecki i Karpacki regiony bioklimatyczne Polski (Błażejczyk, 2004). Punkty pomiarowe były zlokalizowane w 3 rodzajach rzeźby terenu: w dnach dolin, na zboczach i na grzbietach. Jeżeli chodzi o zagospodarowanie terenu, uwzględniono następujące typy: zabudowa luźna i zwarta, las, polana, teren otwarty (tab. 2). W odniesieniu do dolin uwzględniono ich szerokość i głębokość. Jako kryterium rozdzielające doliny szerokie od wąskich przyjęto szerokość dna doliny równą $200 \mathrm{~m}$, a jako rozgraniczenie dolin płytkich i głębokich - wysokość od dna doliny do krawędzi wysoczyzny lub grzbietu rozdzielającego równą $50 \mathrm{~m}$.

\section{Zbocza}

Analizując odchylenia temperatury (średniej, maksymalnej i minimalnej) na zboczach, uwzględniono formę zagospodarowania terenu oraz wysokość i ekspozycję punktu pomiarowego. Stanowiska znajdowały się na wysokości od 5 do 300 m nad dnem dolin, na zboczach o ekspozycji wschodniej, zachodniej, północnej i południowej. Trzy stanowiska były położone na grzbiecie wzniesień.

Zaznacza się wyraźne obniżanie odchyleń temperatury średniej (ryc. 9A) i maksymalnej (ryc. 9B) wraz ze wzrostem wysokości nad dnem doliny. Natomiast w przypadku temperatury minimalnej (ryc. 9C) jej zmiany wraz z wyniesieniem nad dno doliny są niewielkie. Niemniej zaznaczają się dwie strefy stosunkowo chłodne: $<20 \mathrm{~m}$ i $>100 \mathrm{~m}$. W pierwszym przypadku może się to wiązać z pionowym zasięgiem zastoisk chłodu, a w drugim - ze spadkiem temperatury wraz z wysokością.

Zbadano także zależności statystyczne między wyniesieniem punktu pomiarowego nad dno doliny - oddzielnie na zboczach niezalesionych i zalesionych a odchyleniami temperatury. W przypadku $\mathrm{dT}_{\max } \mathrm{i} \mathrm{dT}_{\text {avg }}$ są to związki istotne statystycznie, opisane funkcją wielomianową II stopnia, o współczynnikach determinacji 45-56 \% (ryc. 10, 11). Na zboczach niezalesionych (ryc. 10) zaznacza się spadek temperatury wraz z wysokością oraz wyraźny wzrost temperatury maksymalnej w środkowych częściach zboczy, na 20-70 metrach nad dnem doliny. Na zboczach zalesionych zaś spadek temperatury wraz z wysokością jest nieznaczny (ryc. 11), widać natomiast wyraźnie ochładzający wpływ samego lasu w ciągu dnia - uwidacznia się to w średnich wartościach $\mathrm{d} T_{\max }$, które wynoszą od -2 do $-3^{\circ} \mathrm{C}$.

Znaleziono istotne statystycznie związki między wyniesieniem punktu pomiarowego $(x)$ nad dnem doliny a wartościami odchyleń temperatury na nich obserwowanej. Opisują je następujące równania regresji:

- teren niezalesiony: $\mathrm{d} T_{\max }=-0,0006 \cdot x^{2}+0,66 \cdot x+0,5062$

$\mathrm{d} T_{\text {avg }}=-0,0002 \cdot x^{2}+0,0169 \cdot x+0,4943 ;$

- teren zalesiony: $\quad \mathrm{d} T_{\max }=-0,0001 \cdot x^{2}+0,006 \cdot x-1,8873$

$$
\mathrm{d} T_{\mathrm{avg}}=-0,0002 \cdot x^{2}+0,0136 \cdot x-0,7361 \text {. }
$$


A ${ }^{\circ} \mathrm{C}$

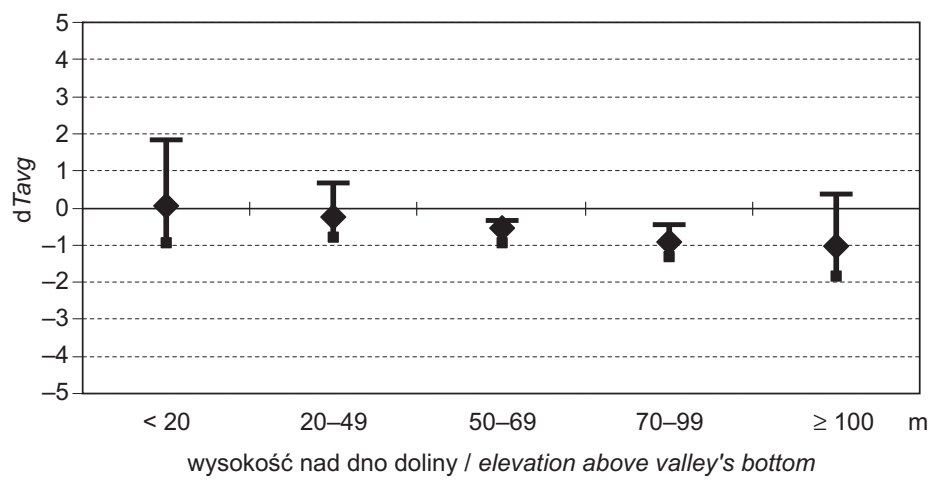

B ${ }^{\circ} \mathrm{C}$

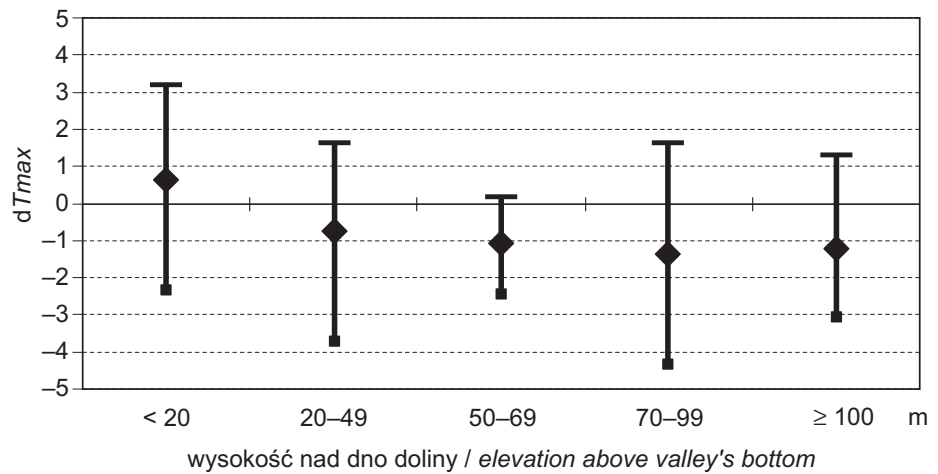

C ${ }^{\circ} \mathrm{C}$

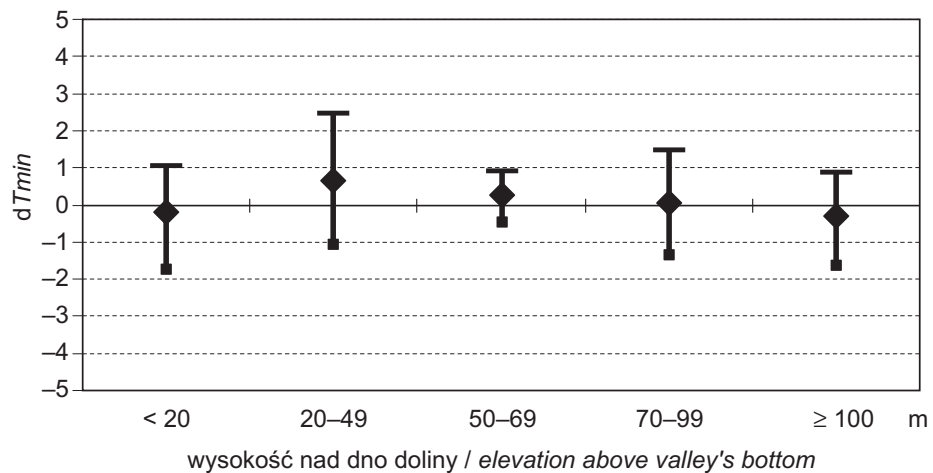

Odchylenia / Deviations:

- największe / largest $\diamond$ średnie / mean najmniejsze / smallest

Ryc. 9. Odchylenia (w odniesieniu do warunków standardowych) średniej (A), maksymalnej (B) i minimalnej (C) dobowej temperatury powietrza na zboczach przy różnej wysokości nad dno doliny

Deviations (from standard conditions) of mean (A), maximum (B) and minimum (C)

24-hour temperatures at various elevations above a valley bottom 
Tabela 2. Charakterystyki badanych obszarów wyżynnych i górskich

Characteristics of the studied upland and mountains areas

\begin{tabular}{|c|c|c|c|c|c|c|}
\hline $\begin{array}{l}\text { Miejsco- } \\
\text { wość } \\
\text { Locality }\end{array}$ & $\begin{array}{l}\text { Liczba } \\
\text { mieszk. } \\
\text { (tys.) } \\
\text { No. of } \\
\text { inhab. } \\
\text { ('000) }\end{array}$ & $\begin{array}{c}\text { Ekspozycja zbocza } \\
\text { i wysokość nad dno } \\
\text { doliny (m) } \\
\text { Aspect and eleva- } \\
\text { tion above valley } \\
\text { floor }\end{array}$ & $\begin{array}{c}\text { Szerokość } \\
\text { i głębokość } \\
\text { doliny } \\
\text { Width and } \\
\text { depth of } \\
\text { valley }\end{array}$ & $\begin{array}{c}\text { Rodzaj zago- } \\
\text { spodarowania } \\
\text { terenu } \\
\text { Type of land } \\
\text { use }\end{array}$ & $\begin{array}{l}\text { Najbliższa } \\
\text { stacja meteo- } \\
\text { rologiczna } \\
\text { Nearest } \\
\text { meteorologi- } \\
\text { cal station }\end{array}$ & $\begin{array}{l}\text { Długość } \\
\text { pomia- } \\
\text { rów } \\
\text { Period of } \\
\text { measure- } \\
\text { ments }\end{array}$ \\
\hline \multirow{3}{*}{$\begin{array}{l}\text { Czernia- } \\
\text { wa-Zdrój }\end{array}$} & \multirow[t]{3}{*}{0,3} & E, 25 & - & las / forest & \multirow{3}{*}{$\begin{array}{l}\text { Jelenia } \\
\text { Góra }\end{array}$} & \multirow{3}{*}{$\begin{array}{l}2 \text { miesią- } \\
\text { ce } \\
2 \text { months }\end{array}$} \\
\hline & & E, 20 & - & zlw & & \\
\hline & & - & w, g & $z \ln$ & & \\
\hline \multirow{3}{*}{$\begin{array}{l}\text { Długopole- } \\
\text { Zdrój }\end{array}$} & \multirow[t]{3}{*}{0,5} & $\mathrm{E}, 5$ & - & $z \ln$ & \multirow[t]{3}{*}{ Kłodzko } & \multirow{3}{*}{$\begin{array}{l}1,5 \text { mie- } \\
\text { siąca } \\
1.5 \\
\text { month }\end{array}$} \\
\hline & & $\mathrm{E}, 10$ & - & zln & & \\
\hline & & - & sz, g & $z \ln$ & & \\
\hline \multirow{2}{*}{$\begin{array}{l}\text { Duszniki- } \\
\text { Zdrój }\end{array}$} & \multirow[t]{2}{*}{5} & - & w, g & zlw & \multirow[t]{2}{*}{ Kłodzko } & \multirow{2}{*}{$\begin{array}{l}1,5 \text { mie- } \\
\text { siąca } \\
1.5 \\
\text { month }\end{array}$} \\
\hline & & - & sz, g & ZZW & & \\
\hline \multirow{3}{*}{$\begin{array}{l}\text { Gaik- } \\
\text { Brzezowa }\end{array}$} & \multirow[t]{3}{*}{0,1} & $\mathrm{~N}, 5$ & - & las / forest & \multirow[t]{3}{*}{ Kraków } & \multirow{3}{*}{$\begin{array}{l}2 \text { tygo- } \\
\text { dnie } \\
2 \text { weeks }\end{array}$} \\
\hline & & $\mathrm{E}, 5$ & - & $\begin{array}{l}\text { teren otwarty } \\
\text { open area }\end{array}$ & & \\
\hline & & grzbiet/ridge, 15 & - & $\begin{array}{l}\text { teren otwarty } \\
\text { open area }\end{array}$ & & \\
\hline \multirow{5}{*}{$\begin{array}{l}\text { Głucho- } \\
\text { łazy }\end{array}$} & \multirow[t]{5}{*}{15} & S, 10 & - & $z \ln$ & \multirow[t]{5}{*}{ Głuchołazy } & \multirow{5}{*}{$\begin{array}{l}5 \text { tygodni } \\
5 \text { weeks }\end{array}$} \\
\hline & & $\mathrm{E}, 110$ & - & las / forest & & \\
\hline & & \begin{tabular}{|l|}
$\mathrm{N}, 100$ \\
\end{tabular} & - & las / forest & & \\
\hline & & $\begin{array}{l}- \\
\end{array}$ & w, g & zlw & & \\
\hline & & - & sz, p & ZZW & & \\
\hline \multirow{3}{*}{$\begin{array}{l}\text { Iwonicz- } \\
\text { Zdrój }\end{array}$} & \multirow[t]{3}{*}{4,5} & E, 70 & - & zlw & \multirow[t]{3}{*}{ Krosno } & \multirow{3}{*}{$\begin{array}{l}1 \text { miesiacc } \\
1 \text { month }\end{array}$} \\
\hline & & $\mathrm{E}, 55$ & - & \begin{tabular}{|l|} 
polana \\
forest clearing
\end{tabular} & & \\
\hline & & - & w, g & zlw & & \\
\hline \multirow[t]{4}{*}{$\begin{array}{l}\text { Jarnoł- } \\
\text { tówek }\end{array}$} & \multirow[t]{4}{*}{0,8} & $\mathrm{~N}, 90$ & - & $\begin{array}{l}\text { teren otwarty } \\
\text { open area }\end{array}$ & \multirow[t]{4}{*}{ Głuchołazy } & \multirow[t]{4}{*}{$\begin{array}{l}5 \text { tygodni } \\
5 \text { weeks }\end{array}$} \\
\hline & & - & $\mathrm{sz}, \mathrm{p}$ & $\begin{array}{l}\text { teren otwarty } \\
\text { open area }\end{array}$ & & \\
\hline & & - & w, g & $\mathrm{zln}$ & & \\
\hline & & - & W, g & zzn & & \\
\hline \multirow[t]{2}{*}{$\begin{array}{l}\text { Jedlina- } \\
\text { Zdrój }\end{array}$} & \multirow[t]{2}{*}{5} & $\mathrm{~N}, 20$ & - & zl n & \multirow[t]{2}{*}{$\begin{array}{l}\text { Jelenia } \\
\text { Góra }\end{array}$} & $\begin{array}{l}2 \text { miesią- } \\
\text { ce }\end{array}$ \\
\hline & & - & w, p & zzn & & \\
\hline $\begin{array}{l}\text { Kudowa- } \\
\text { Zdrój }\end{array}$ & 10 & grzbiet/ridge, 100 & - & $\begin{array}{l}\text { teren otwarty } \\
\text { open area }\end{array}$ & Kłodzko & $\begin{array}{l}1,5 \text { mie- } \\
\text { siąca }\end{array}$ \\
\hline & & - & sz, g & zlw & & \\
\hline & & - & sz, p & Zzn & & month \\
\hline
\end{tabular}




\begin{tabular}{|c|c|c|c|c|c|c|}
\hline $\begin{array}{l}\text { Miejsco- } \\
\text { wość } \\
\text { Locality }\end{array}$ & $\begin{array}{l}\text { Liczba } \\
\text { mieszk. } \\
\text { (tys.) } \\
\text { No. of } \\
\text { inhab. } \\
\text { ('000) }\end{array}$ & $\begin{array}{c}\text { Ekspozycja zbocza } \\
\text { i wysokość nad dno } \\
\text { doliny }(\mathrm{m}) \\
\text { Aspect and eleva- } \\
\text { tion above valley } \\
\text { floor }\end{array}$ & $\begin{array}{c}\text { Szerokość } \\
\text { i głębokość } \\
\text { doliny } \\
\text { Width and } \\
\text { depth of } \\
\text { valley }\end{array}$ & $\begin{array}{c}\text { Rodzaj zago- } \\
\text { spodarowania } \\
\text { terenu } \\
\text { Type of land } \\
\text { use }\end{array}$ & \begin{tabular}{|} 
Najbliższa \\
stacja meteo- \\
rologiczna \\
Nearest \\
meteorologi- \\
cal station
\end{tabular} & $\begin{array}{l}\text { Długość } \\
\text { pomia- } \\
\text { rów } \\
\text { Period of } \\
\text { measure- } \\
\text { ments }\end{array}$ \\
\hline \multirow[t]{4}{*}{$\begin{array}{l}\text { Lądek- } \\
\text { Zdrój }\end{array}$} & \multirow[t]{4}{*}{6} & W, 25 & & \begin{tabular}{|l|} 
polana \\
forest clearing
\end{tabular} & \multirow[t]{4}{*}{ Kłodzko } & \multirow{4}{*}{$\begin{array}{l}2 \text { miesią- } \\
\text { ce } \\
2 \text { months }\end{array}$} \\
\hline & & - & sz, g & park / park & & \\
\hline & & - & w, gł & $\begin{array}{l}\text { teren otwarty } \\
\text { open area }\end{array}$ & & \\
\hline & & - & w, g & zzn & & \\
\hline \multirow[t]{2}{*}{ Latoszyn } & \multirow[t]{2}{*}{1,7} & $\mathrm{~N}, 65$ & - & las / forest & \multirow[t]{2}{*}{ Tarnów } & \multirow{2}{*}{$\begin{array}{l}2 \text { miesia- } \\
\text { ce } \\
2 \text { months }\end{array}$} \\
\hline & & $\mathrm{N}, 20$ & - & \begin{tabular}{|l|} 
teren otwarty \\
open area
\end{tabular} & & \\
\hline \multirow[t]{3}{*}{ Polańczyk } & \multirow[t]{3}{*}{0,8} & grzbiet/ridge, 10 & - & $\mathrm{ZZn}$ & \multirow[t]{3}{*}{ Lesko } & \multirow{3}{*}{$\begin{array}{l}5 \text { tygodni } \\
5 \text { weeks }\end{array}$} \\
\hline & & - & $\mathrm{sz}, \mathrm{p}$ & zlw & & \\
\hline & & - & $\mathrm{sz}, \mathrm{p}$ & ZZW & & \\
\hline \multirow{3}{*}{$\begin{array}{l}\text { Polanica- } \\
\text { Zdrój }\end{array}$} & \multirow[t]{3}{*}{7} & E, 20 & - & Zzn & \multirow[t]{3}{*}{ Kłodzko } & \multirow{3}{*}{$\begin{array}{l}2 \text { miesią- } \\
\text { ce } \\
2 \text { months }\end{array}$} \\
\hline & & $\mathrm{E}, 65$ & - & las / forest & & \\
\hline & & - & sz, p & ZZW & & \\
\hline \multirow{3}{*}{$\begin{array}{l}\text { Rymanów- } \\
\text { Zdrój }\end{array}$} & \multirow[t]{3}{*}{3,5} & \begin{tabular}{|l|} 
W, 30 \\
\end{tabular} & - & zlw & \multirow[t]{3}{*}{ Krosno } & \multirow{3}{*}{$\begin{array}{l}5 \text { tygodni } \\
5 \text { weeks }\end{array}$} \\
\hline & & - & sz, g & zlw & & \\
\hline & & - & w, g & \begin{tabular}{|l|} 
polana \\
forest clearing
\end{tabular} & & \\
\hline \multirow[t]{3}{*}{$\begin{array}{l}\text { Szczaw- } \\
\text { nica }\end{array}$} & \multirow[t]{3}{*}{6} & S, 130 & - & $\begin{array}{l}\text { teren otwarty } \\
\text { open area }\end{array}$ & \multirow[t]{3}{*}{ Nowy Sącz } & \multirow{3}{*}{$\begin{array}{l}2,5 \text { mie- } \\
\text { siąca } \\
2.5 \\
\text { month }\end{array}$} \\
\hline & & - & sz, g & zzn & & \\
\hline & & - & w, g & ZZW & & \\
\hline \multirow{3}{*}{\begin{tabular}{|l|} 
Świera- \\
dów-Zdrój
\end{tabular}} & \multirow[t]{3}{*}{4,5} & \begin{tabular}{|l|} 
E, 20 \\
\end{tabular} & - & zlw & \multirow[t]{3}{*}{\begin{tabular}{|l|} 
Jelenia Góra \\
\end{tabular}} & \multirow{3}{*}{$\begin{array}{l}2 \text { miesią- } \\
\text { ce } \\
2 \text { months }\end{array}$} \\
\hline & & $\mathrm{E}, 85$ & - & las / forest & & \\
\hline & & E, 30 & - & ZZW & & \\
\hline \multirow{3}{*}{\begin{tabular}{l|} 
Szczawno- \\
Zdrój
\end{tabular}} & \multirow[t]{3}{*}{5,5} & - & sz, p & zlw & \multirow[t]{3}{*}{ Jelenia Góra } & \multirow{3}{*}{$\begin{array}{l}1,5 \text { mie- } \\
\text { siąca } \\
1.5 \\
\text { month }\end{array}$} \\
\hline & & - & sz, p & ZZW & & \\
\hline & & - & $\mathrm{sz}, \mathrm{p}$ & park / park & & \\
\hline Wapienne & 0,15 & S, 20 & - & las / forest & Krosno & $\begin{array}{l}3,5 \text { mie- } \\
\text { siaca }\end{array}$ \\
\hline & & - & $\mathrm{z}, \mathrm{g}$ & zlw & & 3.5 \\
\hline & & - & $\mathrm{w}, \mathrm{p}$ & \begin{tabular}{|l|} 
teren otwarty \\
open area
\end{tabular} & & \\
\hline
\end{tabular}

Skróty / Abbreviations: sz - szeroka / wide; w - wąska / narrow; p - płytka / shallow; g - głęboka / deep; zlw - zabudowa luźna wysoka / high non-dense settlement; zln - zabudowa luźna niska / low non-dense settlement; zzw - zabudowa zwarta wysoka / high dense settlement; zzn - zabudowa zwarta niska / low dense settlement. 


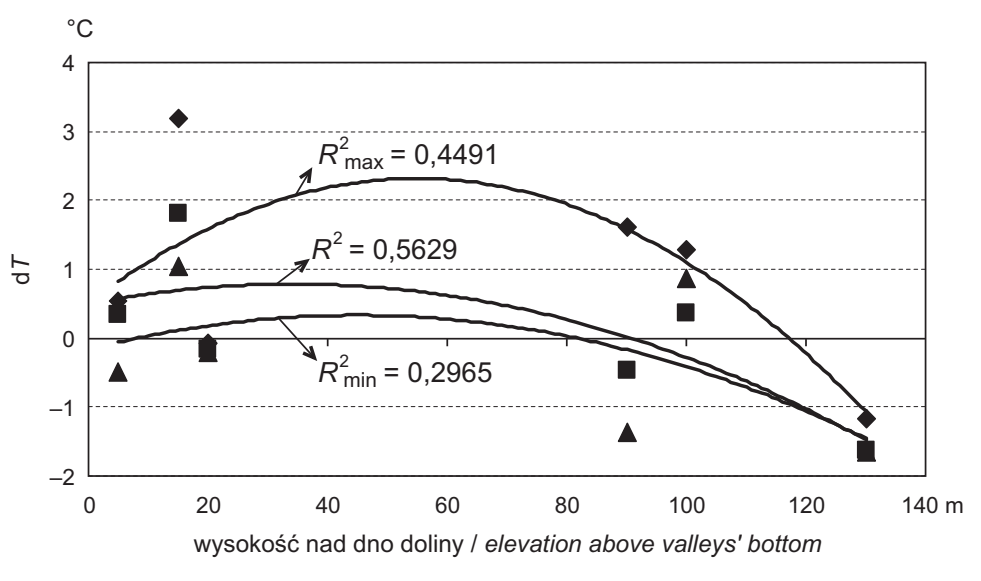

Temperatura / Temperature:

maksymalna / maximum średnia dobowa / mean

$\Delta$ minimalna / minimum

Ryc. 10. Średnie wartości odchyleń temperatury (dT) wraz z liniami trendu na niezalesionych i niezabudowanych zboczach w zależności od wysokości punktu pomiarowego nad dno doliny

Mean values of deviations (dT) from temperatures, along with trend line, for open (unforested, non-built-up) slopes in relation to elevation above a valley bottom

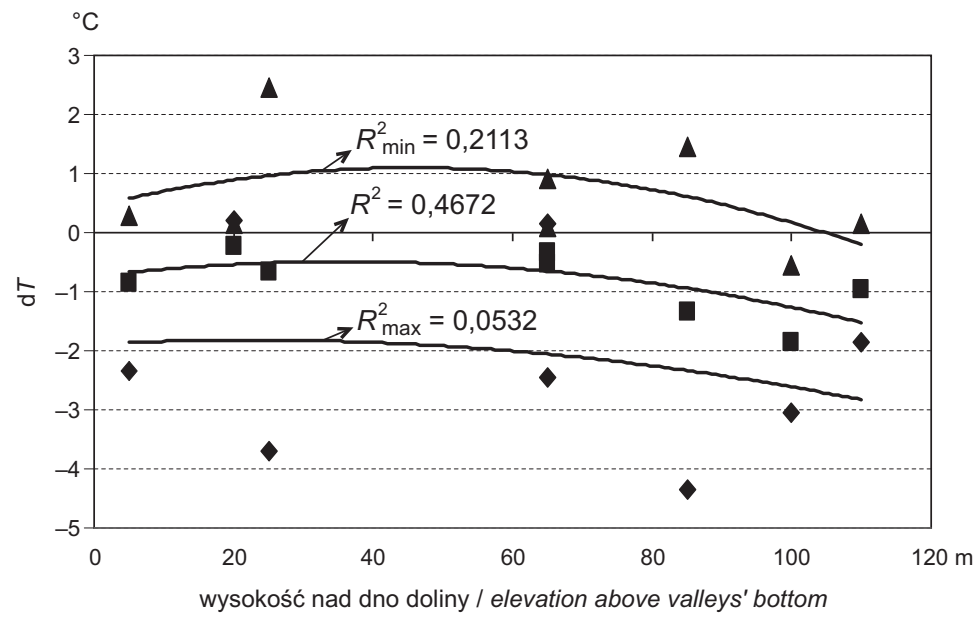

Temperatura / Temperature:

maksymalna / maximum

średnia dobowa / mean

$\Delta$ minimalna / minimum

Ryc. 11. Średnie wartości odchyleń temperatury (dT) wraz z liniami trendu na zalesionych zboczach w zależności od wysokości punktu pomiarowego nad dno doliny

Mean values of deviations (dT) from temperatures, along with trend line, for forested slopes in relation to elevation above a valley bottom 
Odchylenia temperatury minimalnej na zboczach ukazują również, że do wysokości $20 \mathrm{~m}$ nad dnem doliny warunki termiczne są podobne jak w jej dnie jest to prawdopodobnie związane z granicą zasięgu zastoiska chłodnego powietrza (ryc. 9C). Zależność tę widać również wyraźnie w analizie zasięgu wyspy ciepła na zabudowanych zboczach (zabudowa zwarta i luźna). W dolnych partiach zboczy wyspa ciepła zaciera się przez zasięg zastoiska chłodu w dolinie (ryc. 12A i 12B).
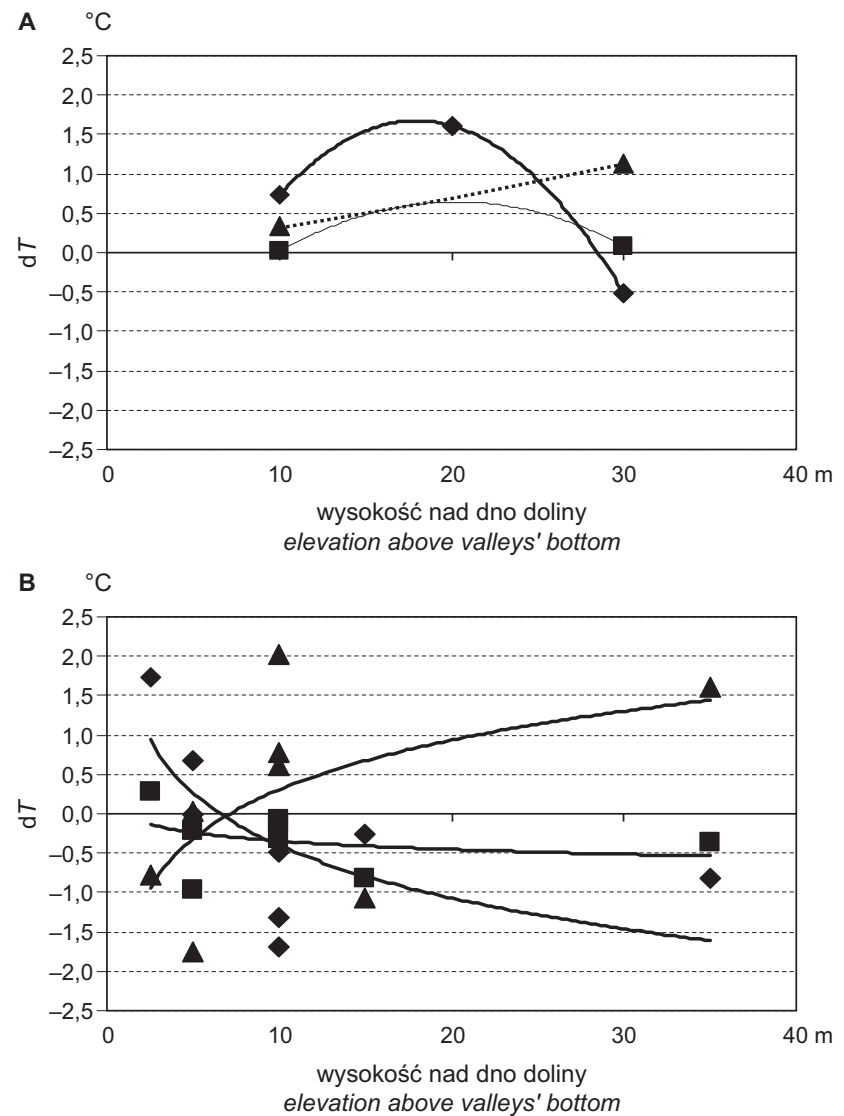

Temperatura / Temperature:

maksymalna / maximum

średnia dobowa / mean

$\Delta$ minimalna / minimum

Ryc. 12. Średnie wartości odchyleń temperatury (dT) wraz z liniami trendu na zboczach o zabudowie zwartej (A) i luźnej (B) w zależności od wysokości punktu pomiarowego nad dnem doliny

Mean values of deviations (dT) from 24-hour air temperatures for slopes with dense (A) and non-dense (B) settlement in relation to elevation above a valley bottom 
Na warunki termiczne zboczy ma również duży wpływ ich ekspozycja. Analiza odchyleń temperatury maksymalnej na zboczach o różnej wystawie wskazuje, że średnie odchylenia $T_{\max }$ osiągają największe ujemne wartości na zboczach północnych (poniżej $-1^{\circ} \mathrm{C}$ ). Zbocza wschodnie, zwłaszcza przy uwzględnieniu temperatury maksymalnej, są cieplejsze od zachodnich, gdyż są często bardziej od nich nasłonecznione (zachmurzenie w górach występuje zazwyczaj w godzinach popołudniowych) (ryc. 13). Najcieplejsze okazały się zbocza o ekspozycji południowej, niemniej średnie odchylenia $\mathrm{d} T_{\max }$ są bliskie zeru, co oznacza podobieństwo do standardowych warunków termicznych.

Wyniki badań ukazują wyraźnie, że na kształtowanie warunków termicznych na stokach górskich zasadniczy wpływ ma wysokość i ekspozycja zbocza, mniejszy zaś zagospodarowanie terenu.

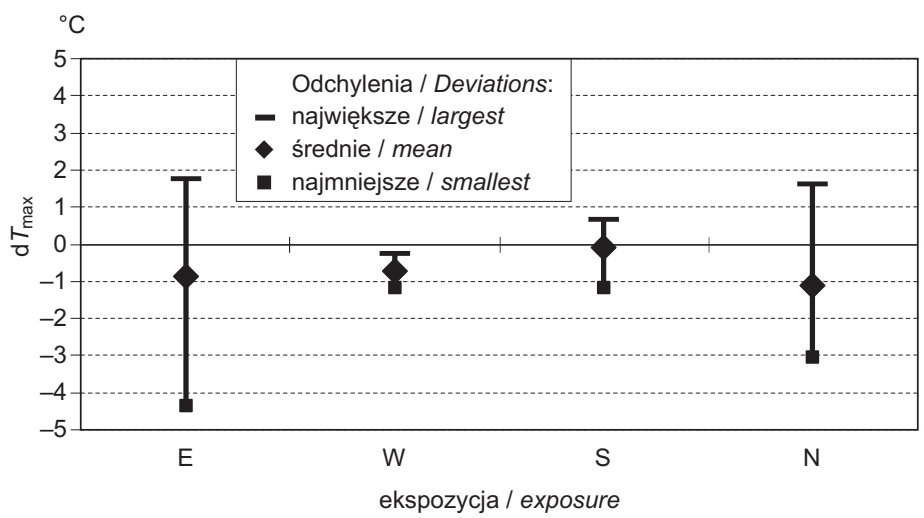

Ryc. 13. Odchylenia (w odniesieniu warunków standardowych) maksymalnej dobowej temperatury powietrza $\left(\mathrm{d} T_{\max }\right)$ na zboczach o różnej ekspozycji

Deviations (from standard conditions) of maximum 24-hour temperatures ( $\left.\mathrm{d} T_{\max }\right)$ on open slopes of differing exposure

\section{Doliny}

W przypadku dolin głównymi czynnikami modyfikującymi warunki termiczne są szerokość i głębokość doliny. Najmniejsze średnie odchylenia temperatury notuje się w dolinach wąskich i głębokich. W dolinach szerokich i płytkich średnia temperatura powietrza może być natomiast wyższa niż w warunkach standardowych (ryc. 14).

Z dolin wąskich, zarówno płytkich jak i głębokich, trudniej usuwa się nagromadzone nocą chłodne powietrze i wolno się ono nagrzewa w ciągu dnia z uwagi na zacienienie dna doliny i osłabienie tam ruchu powietrza. Sprawia to, że średnie odchylenia temperatury maksymalnej są tam bliskie zeru, podczas gdy w dolinach szerokich osiągają wartości ponad $1^{\circ} \mathrm{C}$. Duży zakres wahań tempera- 
tury maksymalnej $\mathrm{w}$ dolinach jest natomiast związany ze sposobem zagospodarowania terenu: wyższą niż w warunkach standardowych temperaturę maksymalną notuje się wśród zabudowy, a niższą w lasach i w parkach (ryc. 15).

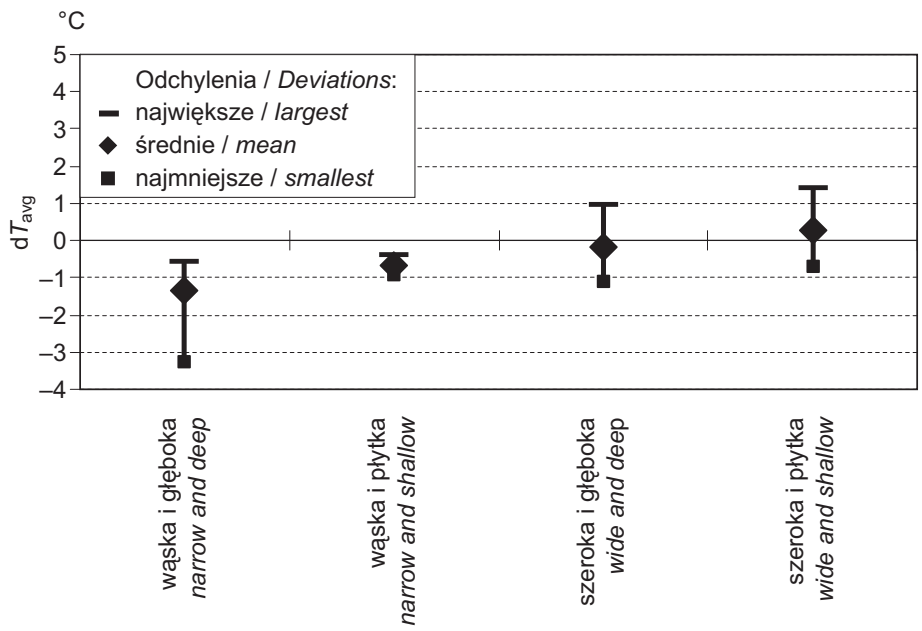

Ryc. 14. Odchylenia (w odniesieniu do warunków standardowych) średniej dobowej temperatury powietrza $\left(\mathrm{d} T_{\text {avg }}\right)$ w różnych typach dolin

Deviations (from standard conditions) of mean 24-hour temperatures ( $\mathrm{d} T_{\mathrm{avg}}$ ) in different types of valley

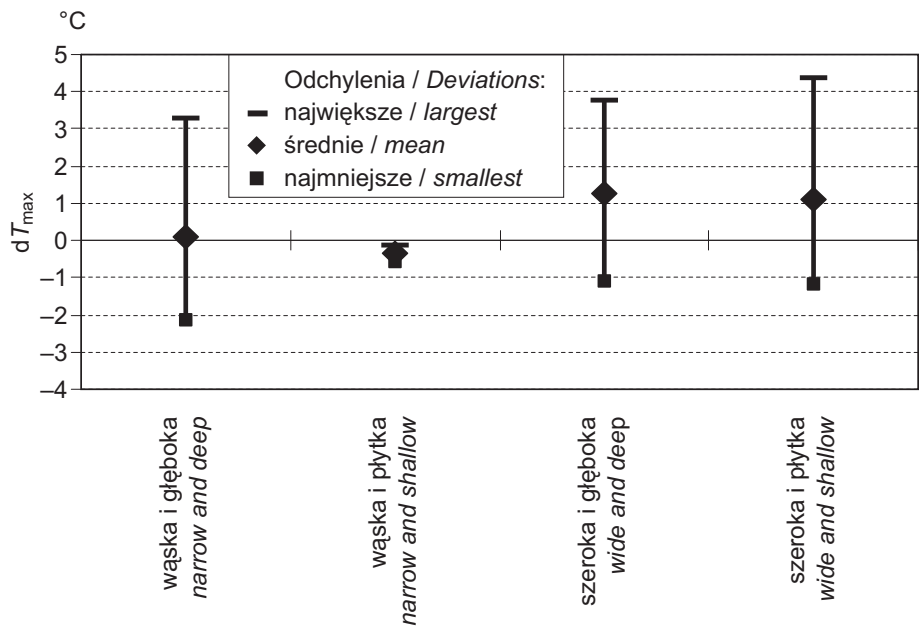

Ryc. 15. Odchylenia (w odniesieniu do najbliższej warunków standardowych) maksymalnej dobowej temperatury powietrza $\left(\mathrm{d} T_{\max }\right)$ w różnych typach dolin Deviations (from standard conditions) of maximum daily temperature ( $\left.\mathrm{d} T_{\max }\right)$ in different types of valley 
W dolinach wąskich niższa jest także temperatura minimalna, w stosunku zarówno do warunków standardowych, jak i do szerokich dolin. Jej odchylenia wynoszą od $0^{\circ} \mathrm{C}$ do prawie $-4^{\circ} \mathrm{C}$, niezależnie od sposobu zagospodarowania terenu w punkcie pomiarowym. Stosunki termiczne najbardziej zbliżone do warunków standardowych panują rano w dnach dolin szerokich i płytkich (ryc. 16).

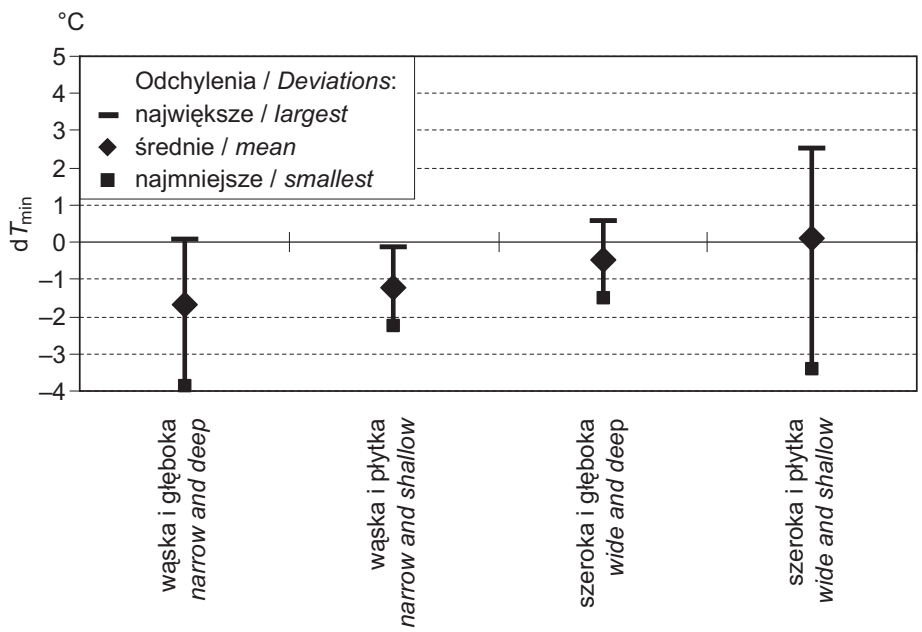

Ryc. 16. Odchylenia (w odniesieniu do warunków standardowych) minimalnej dobowej temperatury powietrza $\left(\mathrm{d} T_{\min }\right)$ w różnych typach dolin

Deviations (from standard conditions) of minimum daily temperature ( $\left.\mathrm{d} T_{\min }\right)$ in different types of valley

\section{Podsumowanie}

Uzyskane wyniki badań potwierdziły wpływ różnych cech krajobrazu na kształtowanie warunków termicznych w skali lokalnej. Na terenach miast położonych na nizinach, najcieplejsze są obszary zabudowane, szczególnie o zabudowie zwartej. Lasy charakteryzuje temperatura niższa nie tylko od terenów zabudowanych, ale także $\mathrm{w}$ porównaniu z warunkami standardowymi. Niemniej wartości temperatury zależą od rodzaju zbiorowiska roślinnego i jego gęstości. Zabudowa śródleśna znacząco wpływa na mikroklimat lasu, podnosząc temperaturę ponad poziom standardowy.

Wielkość miasta ma zdecydowany wpływ na podwyższenie wartości temperatury na terenach objętych intensywnym działaniem miejskiej wyspy ciepła. Jest to szczególnie widoczne w obrębie zabudowy zwartej wysokiej i luźnej wysokiej oraz parków śródmiejskich.

Na obszarach określanych w dokumentacji badań topoklimatycznych jako „teren otwarty” wartości temperatury powietrza, zwłaszcza średnie i maksymalne, były zbliżone do obserwowanych $\mathrm{w}$ warunkach standardowych, repre- 
zentowanych przez najbliższą stację meteorologiczną. Świadczy to o tym, że nawet na niewielkich obszarach niezabudowanych w obrębie miast, o stosunkowo swobodnym przepływie powietrza i niewielkim zakryciu horyzontu, warunki termiczne są kształtowane głównie przez czynniki cyrkulacyjne.

Na kształtowanie warunków termicznych na obszarach górskich, zarówno na stokach górskich jak i w dnach dolin, wpływ ma przede wszystkim rzeźba terenu (wysokość nad dno doliny i ekspozycja zbocza oraz szerokość i głębokość doliny), a zagospodarowanie terenu odgrywa rolę drugorzędną.

Uzyskane charakterystyki ilościowe (w postaci równań regresji) odchyleń temperatury powietrza w różnych typach krajobrazu od tzw. warunków standardowych są w wielu przypadkach istotne statystycznie. Obecnie nie mogą być jednak traktowane jak model statystyczny. Ich sprawdzalność musi być potwierdzona na niezależnym materiale pomiarowym. Badania takie zostaną przeprowadzone po zgromadzeniu odpowiednich danych empirycznych.

\section{Piśmiennictwo}

Błażejczyk K., 1996, Topoklimat Warszawy, [w:] W. Stola, J. Grzeszczak (red.), Przemiany struktury przestrzennej obszarów wiejskich w strefach podmiejskich Polski i Rumunii, Conference Papers, 25, IGiPZ PAN, Warszawa, s. 13-25.

-, 2002, Znaczenie czynników cyrkulacyjnych i lokalnych w kształtowaniu klimatu i bioklimatu Aglomeracji Warszawskiej, Dokumentacja Geograficzna, 26, IGiPZ PAN, Warszawa.

-, 2004, Bioklimatyczne uwarunkowania rekreacji i turystyki w Polsce, Prace Geograficzne, IGiPZ PAN, 192, Warszawa.

Błażejczyk K., Bąkowska M., Więcław M., 2006, Urban heat island in large and small cities, [w:] 6th International Conference on Urban Climate, Preprints, June 12-16 2006, Göteborg University, Göteborg, Sweden, s. 794-797.

Błażejczyk K., Kunert A., 2006, Differentiation of bioclimatic conditions of urban areas (the case of Poland), [w:] 6th International Conference on Urban Climate, Preprints, June 12-16 2006, Göteborg University, Göteborg, Sweden, s. 213-216.

Fortuniak K., 2003, Miejska wyspa ciepta, Wydawnictwo Uniwersytetu Łódzkiego, Łódź.

Geiger R., 1969, Topoclimates, [w:] H.E. Landsberg, H. Flohn (red.), World Survey of Climatology, 2, General Climatology, 2, Elsevier, Amsterdam-London-New York, s. $105-138$.

Hess M., 1968, Metoda określenia ilościowego zróżnicowania mezoklimatycznego w terenach górskich, Zeszyty Naukowe UJ, Prace Geograficzne, 18, Kraków.

Kondracki J., 2000, Geografia regionalna Polski, Wydawnictwo Naukowe PWN, Warszawa.

Lee R., 1978, Forest Microclimatology, Columbia University Press, New York.

Oke T. R., 1987, Boundary Layer Climates, Methuen, London-New York.

Paszyński J., Miara K., Skoczek J., 1999, Wymiana energii między atmosfera a podtożem jako podstawa kartowania topoklimatycznego, Dokumentacja Geograficzna, 14, IGiPZ PAN, Warszawa.

Trepińska J., 2002, Górskie klimaty, Instytut Geografii i Gospodarki Przestrzennej UJ, Kraków.

[Wpłynęło: wrzesień 2010; poprawiono: styczeń 2011 r.] 


\section{ANNA KUNERT, KRZYSZTOF BŁAŻEJCZYK}

\section{LOCAL-SCALE AIR-TEMPERATURE DIFFERENCES IN VARIOUS TYPES OF POLAND'S LANDSCAPE}

Recent years have brought much climatic research relating to local-scale spatial differences in meteorological variables. Data from standard meteorological observations are quite separate from this since they concern open, flat areas, with slight obstruction of the horizon, which is to say the standard meteorological conditions and observations used to account for general climatic processes on the meso- and macro-scales. In contrast, local-scale (topoclimatic) research seeks to assess the role of various types of landscape (different relief, land use, ground cover and horizon obstruction) in shaping the spatial distribution of climate on the local scale. Presented here are the results of topoclimatic investigations performed in various types of local landscape in different regions of Poland, in the years 2001-2008. The aim was to define the influence of different local-scale landscape components on thermal conditions.

Air temperature (Ta) was measured at $1.2-1.5 \mathrm{~m}$ above the ground using HOBO Pro data loggers (from the Onset Computer Corp.). The series of measurements were of between 2 weeks' and 6 months' duration, and were representative of the warm (AprilOctober) period of the year. The registered (10-minute average) Ta values provided a basis for calculations of temperature characteristics. Mean daily temperature $\left(T_{\mathrm{avg}}\right)$ was calculated by averaging registered temperature values, while the maximum $\left(T_{\max }\right)$ and minimum $\left(T_{\min }\right)$ daily temperatures were taken to be the highest and lowest values registered for each day. As a reference, standard-condition data from the nearest meteorological station for the period of observations were used. The NOAA meteorological database was applied for this purpose. Differences in analysed temperature characteristics $\left(\mathrm{d} T_{\text {avg }}\right.$, $\left.\mathrm{d} T_{\max }, \mathrm{d} T_{\min }\right)$ between local sites and standard-condition environments were then calculated.

The results show individual patterns to the air-temperature deviations in different types of landscape. Not unnaturally, downtown areas and densely-settled residential districts are found to sustain significant elevations of air temperature beyond what is observed in standard conditions. In turn, parks, forests and the banks of watercourses are cooler than the reference area in daytime hours. Equally, "open areas" within cities (with relatively free air flows and limited horizon shading) do not differ significantly from standard meteorological conditions.

In mountain areas, air temperature is found to be modified by two local factors: type of relief and type of land use. The warmest areas are on the middle parts of south-facing slopes elevated 20-70 m above a valley bottom. The lower parts of slopes are usually under the influence of cold lakes, while upper parts are influenced more tangibly by the universal phenomenon of gradual temperature decrease with increasing altitude. In valley bottoms, the effect of the urban heat island in settled areas is reduced to some extent by cool air flowing down from the slopes.

Overall, it proved possible to detect a statistically significant influence of particular types of landscape on air temperature. However, the relevant regression equations may not be used as statistical models for air-temperature distribution on a local scale, since they require verification by reference to an independent dataset. Research will thus be continued in the near future to furnish the new experimental data necessary for the verification in question. 